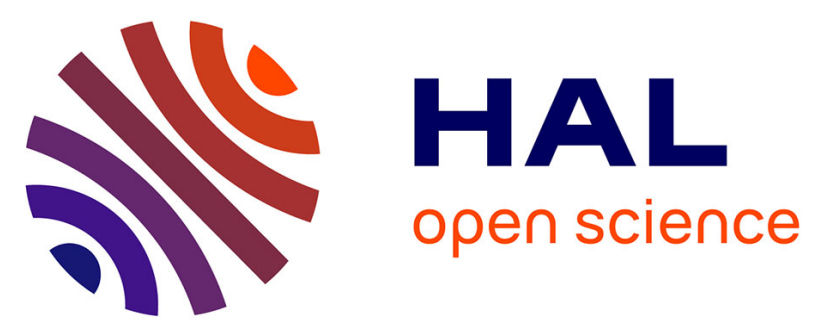

\title{
Ribosomal proteins of Tetrahymena thermophila. Correlation of one-and two-dimensional electrophoretic migration patterns and characterization of additional small and large subunit proteins
}

Françoise Hayes, Barbara Petridou, Marie-France Guerin, Franqoise Hayes

\section{To cite this version:}

Françoise Hayes, Barbara Petridou, Marie-France Guerin, Franqoise Hayes. Ribosomal proteins of Tetrahymena thermophila. Correlation of one-and two-dimensional electrophoretic migration patterns and characterization of additional small and large subunit proteins. Biochimie, 1989, 71 (5), pp.655665. 10.1016/0300-9084(89)90160-0 . hal-03187316

\section{HAL Id: hal-03187316 \\ https: / hal.inrae.fr/hal-03187316}

Submitted on 31 Mar 2021

HAL is a multi-disciplinary open access archive for the deposit and dissemination of scientific research documents, whether they are published or not. The documents may come from teaching and research institutions in France or abroad, or from public or private research centers.
L'archive ouverte pluridisciplinaire HAL, est destinée au dépôt et à la diffusion de documents scientifiques de niveau recherche, publiés ou non, émanant des établissements d'enseignement et de recherche français ou étrangers, des laboratoires publics ou privés.

\section{(ㅇ)(1) $\$$}

Distributed under a Creative Commons Attribution - NonCommercial - NoDerivatives 44.0 


\title{
Ribosomal proteins of Tetrahymena thermophila. Correla- tion of one- and two-dimensional electrophoretic migration patterns and characterization of additional small and large subunit proteins
}

\author{
Barbara PETRIDOU, Marie-France GUERIN, and Françoise HAYES* \\ Laboratoire de Chimie Cellulaire, Institut de Biologie Physico-Chimique, 13 rue Pierre et Marie Curie, \\ Paris 75005, France
}

(Received 12-12-1988, accepted 26-1-1989)

Summary - Further analysis of the protein complement of the cytoplasmic ribosome of the protozoon Tetrahymena thermophila has led to the identification and characterization of seven additional proteins, three in the small and four in the large subunit of this ribosome. Several of these proteins are poorly soluble or insoluble in the absence of high concentrations of urea and are not seen in the electrophoretic distribution patterns of ribosomal proteins in two-dimensional polyacrylamide gels unless $6 \mathrm{M}$ urea is added to electrode buffers in contact with protein samples (first dimension) and first-dimension gels (second dimension). The migration patterns of the $40 \mathrm{~S}$ and $60 \mathrm{~S}$ subunits of the $T$. thermophila ribosome in one-dimensional polyacrylamide SDS gels and in two-dimensional gels prepared by means of the basic-acidic system of Kaltschmidt and Wittmann**, and the basic-SDS system of Zinker and Warner*** have been correlated.

Tetrahymena / ribosome / protein / electrophoresis

\section{Introduction}

In a previous publication [1] 31 proteins from the small, and 41 from the large subunit of the cytoplasmic ribosome of Tetrahymena thermophila were characterized and their molecular weights were estimated by one- and two-dimensional electrophoresis. This study left in doubt the status of one protein, provisionally designated S1, associated with the small ribosomal subunit, and of several species present in some but not all protein preparations analysed. Further work has produced evidence that confirms the ribosomal status of protein S1 and has led to the identification of three additional proteins in the small ribosomal subunit and of four in the large subunit.

\section{Materials and methods}

\section{Strains and culture conditions}

T. thermophila B1868 mating type IV (Dr D. Nanney, Dept. of Zoology, University of Illinois, Urbana, IL. USA) was grown as described previously [2]. Cells were labelled with $\left[{ }^{35} \mathrm{~S}\right]-\mathrm{L}-\mathrm{methio}-$ nine (Amersham, U.K.) sp. act. $30 \mathrm{Tbq} / \mathrm{mmol}, 18.5$ $\mathrm{MBq} / \mathrm{ml}$ during 6-7 generations of exponential growth in a defined synthetic medium [3] as described in [4].

Preparation of ribosomes, ribosomal subunits, and ribosomal proteins

Ribosomes and their subunits were prepared as described previously, with iodoacetamide as protease

\footnotetext{
*Author to whom correspondence should be aadressed.

**Kaltschmidt E. \& Wittmann H.G. (1976) Anal. Biochem. 36, 401-412 [6].

***Zinker S. \& Warner J.D. (1976) J. Biol. Chem. 251, 1799-1807 [7].
} 
inhibitor in all cases [1, 2]. Protein samples for oneand two-dimensional electrophoresis were prepared as detailed in [1].

\section{Polyacrylamide gel electrophoresis}

One-dimensional electrophoretic separations of ribosomal proteins were carried out according to Laemmli [5] with the minor modification that hydrochloric acid in the stacking gel buffer was replaced by orthophosphoric acid. The procedures of Kaltschmidt and Wittmann [6] and Zinker and Warner [7] were used for two-dimensional electrophoresis with the following modifications.

\section{First-dimension electrophoresis}

Conditions were identical for both two-dimensional procedures.

Separate first-dimension gels $(4 \mathrm{~mm} \times 90 \mathrm{~mm})$ prepared as described by Kaltschmidt and Wittmann [6] were used to fractionate acidic and basic proteins.

Protein samples $(200 \mu \mathrm{g}$ and $300 \mu \mathrm{g}$, respectively, for separation of basic and acidic proteins) were dissolved in Kaltschmidt and Wittmann first-dimension separation gel solution containing $8 \mathrm{M}$ urea $(50 \mu \mathrm{l})$. Pyronine red tracking dye, followed by tetramethylethylene diamine, and ammonium persulfate in the quantities specified by Kaltschmidt and Wittman were then added and the mixtures were immediately layered on to first-dimension gels and allowed to polymerise. Electrophoresis was carried out at $6-8^{\circ} \mathrm{C}$ for $18 \mathrm{~h}$ at $10 \mathrm{~V} / \mathrm{cm}$ with upper electrode buffer (in contact with the protein sample zone) containing $6 \mathrm{M}$ urea.

\section{Second-dimension electrophoresis}

Gel slabs $(1 \mathrm{~mm} \times 135 \mathrm{~mm}$ wide $\times 230 \mathrm{~mm}$ long $)$ for second-dimension electrophoresis according to Kaltschmidt and Wittmann were prepared as described by these authors [6] using an acrylamide concentration of $18 \% \mathrm{wt} / \mathrm{vol}$. Second-dimension gels $(1 \mathrm{~mm}$ $\times 135 \mathrm{~mm} \times 230 \mathrm{~mm}$ ) for the Zinker and Warner procedure were prepared according to Laemmli [5], with hydrochloric acid replaced by orthophosphoric acid in the stacking gels, as already noted. Firstdimension gels were extruded and shortened by removing the sample zone and the lower $15 \mathrm{~mm}$ from gels containing basic proteins and the lower $35 \mathrm{~mm}$ from gels containing acidic proteins. The shortened basic and acidic protein-containing gels were then bonded together, in the appropriate orientation, to second-dimension gel slabs. Second-dimension electrophoresis was carried out as follows: Kaltschmidt and Wittmann method, $6-8^{\circ} \mathrm{C}, 1 \mathrm{~h}$ at $1 \mathrm{~V} / \mathrm{cm}$ followed by $16 \mathrm{~h}$ at $10 \mathrm{~V} / \mathrm{cm}$, upper electrode buffer (in contact with the first-dimension gel) containing $6 \mathrm{M}$ urea; Zinker and Warner procedure, $6-8^{\circ} \mathrm{C}, 1 \mathrm{~h}$ at $1 \mathrm{~V} / \mathrm{cm}$, followed by $16 \mathrm{~h}$ at $8 \mathrm{~V} / \mathrm{cm}$. Gel slabs were stained with Coomassie blue and, when necessary, dried for autoradiography.

\section{Elution of proteins from polyacrylamide gels}

Proteins were eluted from stained zones taken from one- and two-dimensional polyacrylamide gels by incubation of the gel samples for $72 \mathrm{~h}$ at $37^{\circ} \mathrm{C}$ in $0.5 \mathrm{ml}$ of $10 \mathrm{mM}$ Tris- $\mathrm{HCl}, 10 \mathrm{mM} 2$-mercaptoethanol, $0.5 \% \mathrm{wt} / \mathrm{vol}$ sodium dodecyl sulfate (SDS) $\mathrm{pH} 7.6$ and precipitated from the eluates at $0^{\circ} \mathrm{C}$ overnight in the presence of $10 \% \mathrm{wt} /$ vol trichloroacetic acid or of $7 \mathrm{vol}$ of acetone with or without addition of carrier proteins (see figure legends for details). Precipitates were dried briefly in a vacuum after first washing trichloroacetic acid precipitated proteins with diethyl ether, and then dissolved in electrophoresis buffers.

\section{Results}

Correlation of one- and th J-dimensional electrophoretic migration patterns of ribosomal proteins

\section{S subunit proteins}

Although its resolving power is lower than that of two-dimension systems, one-dimensional electrophoretic analysis of ribosomal proteins possesses the advantage of rapidity, permits the comparison of numerous preparations in the same gel slab, and can be used for the preliminary characterization of protein samples if the species present in the various bands seen in onedimensional electrophoregrams have been identified.

To do this, radioactive proteins prepared from $40 \mathrm{~S}$ and $60 \mathrm{~S}$ ribosomal subunits isolated from cells grown in the presence of $\left[{ }^{35} \mathrm{~S}\right]-\mathrm{L}-$-methionine were fractionated by two-dimensional electrophoresis according to Kaltschmidt and Wittmann [6]. Radioactive proteins eluted from each of the 71 spots previously [1] characterized in this sepration system were mixed with total nonradioactive subunit proteins and the mixtures were analysed by one-dimensional electrophoresis according to Laemmli [5]. After electrophoresis gel slabs were stained, dried, and autoradiographed.

In all but two cases a single major radioactive band which comigrated with one of the stained bands in the gel was detected. Exceptions were the spot containing 60 S subunit proteins L26 and L26' (revised numbering) which yielded, as expected, two radioactive bands, and the spot containing 60S subunit protein L39 (revised numbering) which gave no radioactive spot, showing that it contained neither methionine nor 
405

Protein
Bumber Mr Band
original revised (kD)

605

\author{
Protein \\ Number Mr \\ original revised (kD)
}
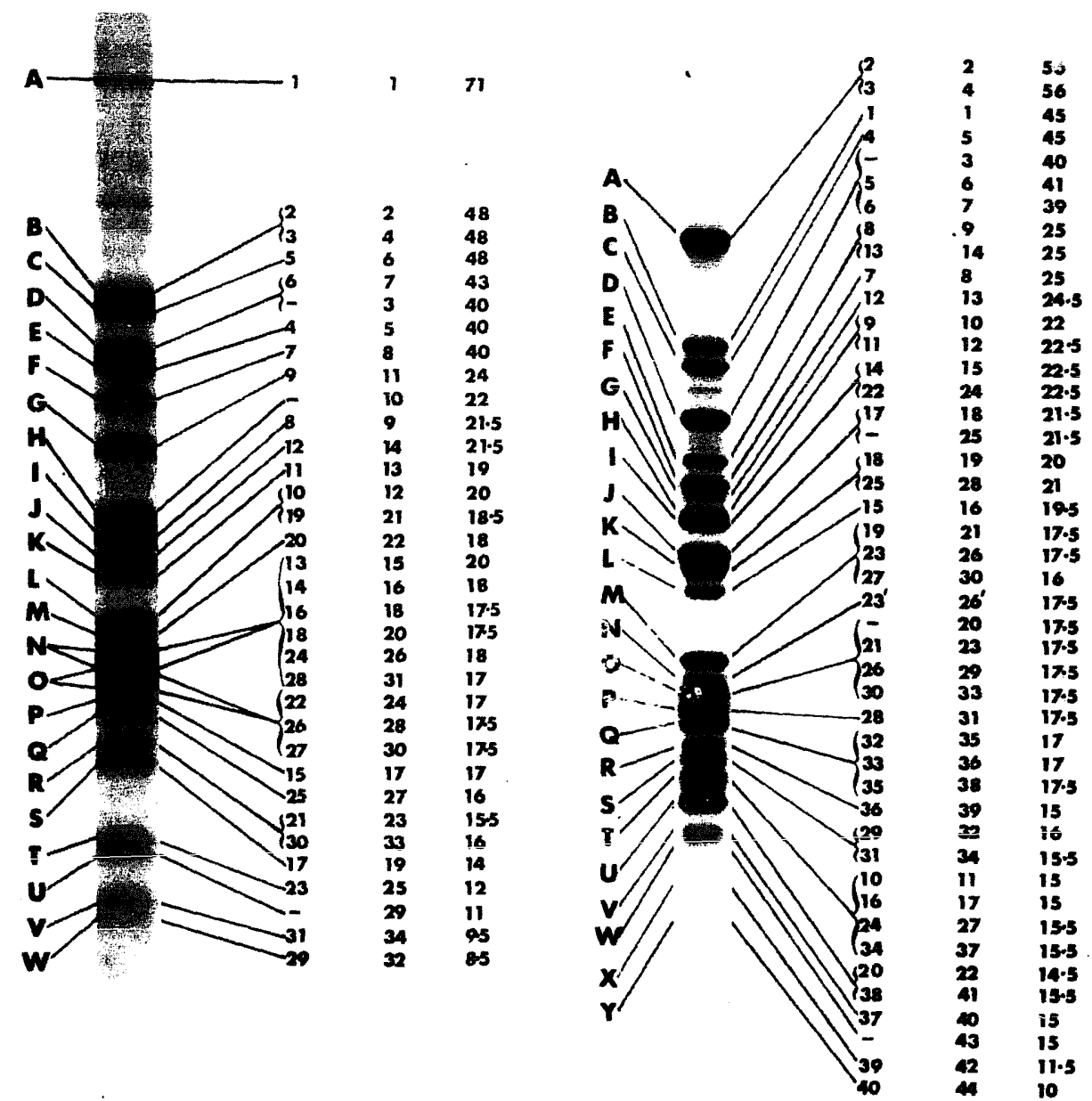

Fig. 1. Correlation of one- and two-dimensional electrophoretic migration patterns of total proteins of the small and large subunits of the cytoplasmic ribosome of $T$. thermophila. Preparations of total proteins isolated from ${ }^{35} \mathrm{~S}$-labeled $40 \mathrm{~S}$ and $60 \mathrm{~S}$ ribosomal sut anits $\left(120 \mu \mathrm{g}\right.$ protein, $\mathrm{sp}$. act. $\left.10^{5} \mathrm{cpm} / \mu \mathrm{g}\right)$ were fractionated by two-dimensional electrophoresis according to Kaltschmidt and Wittmann [6] modified by omission of urea from first-dimension electrode buffers. As reported previously [1], 31 stained spots were observed in the migration pattern of $40 \mathrm{~S}$ subunit proteins and 40 in that of $60 \mathrm{~S}$ subunit proteins.

Central 4-mm diam circular samples ware taken from each of the 71 stained spots and their protein contents were eluted as described in Materials and methods. Samples of each eluate containing $3000-5000 \mathrm{cpm}{ }^{35} \mathrm{~S}$ were mixed with aliquots of solutions of total $40 \mathrm{~S}$ or $60 \mathrm{~S}$ subunit proteins in elution buffer $(30 \mu \mathrm{l}, 1 \mu \mathrm{g}$ protein $/ \mu \mathrm{l})$ and proteins were recovered by acetone precipitation, dried briefly in a vacuum to remove acetone, redissolved in $20 \mu$ l of Laemmli sample buffer, and placed in sample wells of one-dimensional gels prepared according to Laemmli [5]. After electrophoresis, gels were stained, dried, and autoradiographed. The results of a series of such analyses are summarized in Fig. 1.

Resolved bands seen reproducibly in stained gels are designated by capital letters. Individual proteins identified in each band are numbered in the original [i] and revised numbering systems. Protein molecular weight estimates are taken from [1] except for those of the seven newly characterized proteins S3, S10, S29, L3, L20, L25, and L43, the molecular weights of which were estimated during the present study.

Prefixes S and $L$ for small and large subunit proteins are omitted to simplify the figure. We note here that the $60 S$ subunit protein numbered L43 in the revised nomenclature was numbered L41 in a recent publication [8], in which proteins released together with 5S rRNA by EDTA treatment of the 60S subunit of $T$. thermophila were identified. These proteins numbered L4, L15, L24, L31, and L41 in [8] are, respectively, L5, L16, L27, L34, and L43 in the revised nomenclature. 
cysteine (methionine is the primary sulfur source for Tetrahymena which cannot metabolize inorganic sulfur). The results of a series of analyses of this kind, summarized in Fig. 1, showed: (1) that all of the 72 previously characterized ribosomal proteins [1] except L39 are assignable to bands in the one-dimensional electrophoresis patterns of $40 \mathrm{~S}$ and $60 \mathrm{~S}$ subunit proteins; (2) that two bands, $\mathrm{H}$ and $\mathrm{U}$ (Fig. 1), in the $40 \mathrm{~S}$ subunit protein pattern, and two, $R$ and $W$ (Fig. 1) in the 60S subunit protein pattern, do not contain any of these proteins.

On the basis of its known molecular weight [1], protein L39 could plausibly be assigned to $60 S$ subunit band $R$ and this conclusion was confirmed by one-dimensional electrophoretic comparison of nonradioactive protein L39 eluted from spot L39 taken from a heavily loaded Kaltschmidt and Wittmann seconddimension gel slab and total $60 \mathrm{~S}$ subunit proteins (results not shown). Identification of the proteins present in $40 \mathrm{~S}$ subunit bands $\mathrm{H}$ and $\mathrm{U}$ and $60 S$ subunit band $W$ was then undertaken. From the positions in the one-dimensional analysis in Fig. 1 and the known molecular weights of the 72 previously characterized ribosomal proteins [1], those of the proteins present in 40S subunit bands $\mathrm{H}$ and $\mathrm{U}$ and $60 \mathrm{~S}$ subunit $\mathrm{W}$ can be estimated as 22000,11000 , and 15000 , respectively. Absence in two-dimensional electrophoretic analyses of spots corresponding to these proteins could be explained: (1) by loss of material during the extraction of proteins for twodimensional analyses; (2) by exceptionally high first- or second-dimensional electrophoretic mobilities leading to loss of these proteins under standard conditions of two-dimensional electrophoresis; (3) by retention of material in the sample zone of two-dimensional analyses.

The first explanation was eliminated by the presence of these three bands in normal amounts in one-dimensional electrophoretic analyses of acetic acid-extracted proteins, and the second by failure to observe additional high mobility spots in two-dimensional electrophoretic analyses carried out with first- and second-dimension migration times reduced to one-third of the standard values (results not shown). To test the third explanation, the electrophoretic properties of material eluted from $40 \mathrm{~S}$ band $\mathrm{H}$, and concentrated from the eluate by precipitation with trichloroacetic acid after addition of pancreatic RNase as carrier were examined.

As expected, the recovered material migrated as two bands in one-dimensional gels, one at the position of band $\mathrm{H}$, the other at that expected for pancreatic RNase (Fig. 2, track B). Twodimensional electrophoresis of the same material was then carried out according to Kaltschmidt and Wittmann. Two Coomassie bluestained regions were observed after seconddimension electrophoresis, namely the firstdimension sample zone, and a spot at the position expected for pancreatic RNase (result not shown). To confirm that the material present in

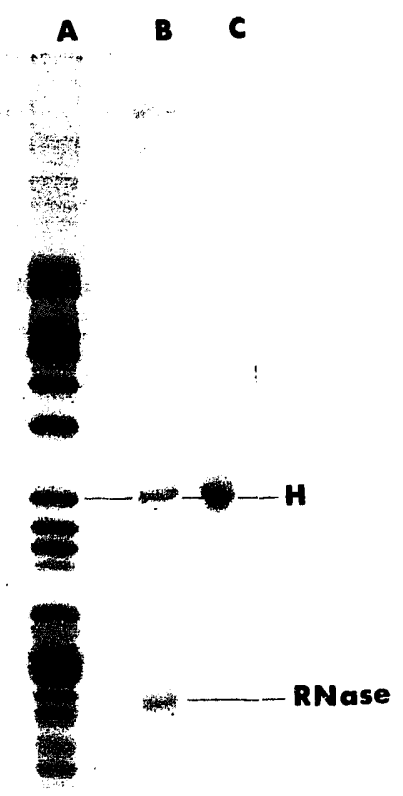

Fig. 2. Eletrophoretic behavior of the protein present in $40 \mathrm{~S}$ band $\mathrm{H}$ (Fig. 1). One-dimensional SDS-polyacrylamide gel electrophoresis was carried out as described by Laemmli [5]. A, Total 40S subunit proteins.

B, Protein eluted from band $\mathrm{H}$. Protein was eluted as described in Materials and methods from $40 \mathrm{~S}$ band $\mathrm{H}$ removed from a heavily loaded one-dimensional gel similar to that shown in Fig. 1. After addition of pancreatic RNase $(5 \mu \mathrm{g})$ as carrier, proteins were recovered from the eluate by acetone precipitation. One-third of the product was dissolved in Laemmli sample buffer and used to obtain the result shown in lane $\mathbf{B}$.

C, Protein present in the sample gel after two-dimensional electrophoresis according to Kaltschmidt and Wittmann [6]. The remaining two-thirds of the material eluted from $40 \mathrm{~S}$ band $H$ was subjected to two-dimensional electrophoresis according to Kaltschmidt and Wittmann using urea-free first-dimension electrode buffer. The first-dimension sample zone was removed from the stained second-dimension gel slab and a $1 \mathrm{~mm}$ thick slice from its center was dialysed briefly against Laemmli sample buffer and then immersed in the same buffer in well $\mathbf{C}$ 
the first-dimension sample zone was the protein in band $\mathrm{H}$, the stained sarnple zone was removed from the gel slab and placed in one sample well of a one-dimensional SDS-containing gel slab. After electrophoresis a single Coomassie bluestained band was seen at the position of band $\mathrm{H}$ (Fig. 2, track C).

These results show that the material eluted from band $H$ possesses unaltered migration properties in one-dimensional SDS polyacrylamide gel electrophoresis, and migrates in neither dimension of two-dimensional electrophoresis according to Kaltschmidt and Wittmann.

Repetition of the preceding experiment using total $40 \mathrm{~S}$ subunit proteins in place of the material extracted from band $\mathrm{H}$ gave similar results. The first-dimension sample zone recovered from the second-dimension gel slab was found to contain large amounts of material which migrated at the position of band $\mathrm{H}$ in a one-dimensional SDScontaining gel together with smaller amounts of components migrating at the positions of several other $40 \mathrm{~S}$ proteins (results not shown). Further experiments were therefore carried out with total $40 \mathrm{~S}$ subunit proteins.

Nonmigration of band $\mathrm{H}$ material in the first dimension of the Kaltschmidt and Wittmann procedure could be caused either by a pI value close or identical to that of the first-dimension electrode buffer ( $\mathrm{pH} \mathrm{8.6)}$ or by low solubility under the conditions of first-dimension electrophoresis; nonmigration in the seconi electrophoretic dimension could be readily accounted for only by low solubility.

Total 40S subunit proteins dissolve rapidly and apparently completely in the first-dimension sample buffer of Kaltschmidt and Wittmann which contains $8 \mathrm{M}$ urea. However, according to the practice of other investigators [9-13], urea was routinely omitted from first-dimension electrode buffers which are in contact with firstdimension sample zones. Under such conditions diffusion of urea from the sample zones would be rapid and could lead to precipitation of proteins possessing low solubility in its absence. Urea (6 M) was therefore added to the firstdimension upper electrode buffer (in contact with the sample zone) in Kaltschmidt and Wittmann, and Zinker and Warner two-dimensional procedures as originally specified by these authors. In addition, the second-dimension upper electrode buffer of Kaltschmidt and Wittmann was modified by addition of $6 \mathrm{M}$ urea.

The results of electrophoretic analyses of total $40 \mathrm{~S}$ subunit proteins using urea-containing upper electrode buffers are shown in Fig. 3A, B. They differ in several respects from those obtained [1] with urea-free upper electrode buffers:

(1) Spot S1 observed previously in small amounts now appears as a relatively strongly stained spot, confirming its status as a ribosomal protein;

(2) An additional strongly stained spot with significant first- and second-dimension mobilities appears in the acidic side of two-dimensional separations (S3, Fig. 3A, B, revised numbering of $40 \mathrm{~S}$ proteins). The spot is not seen if urea-free upper electrode buffers are used for both dimensions of electrophoresis according to Kaltschmidt and Wittmann (see Fig. 4A in [1]) or for he first dimension of electrophoresis according to Zinker and Warner (see Fig. 5A in [1]). It is also not seen if $6 \mathrm{M}$ urea is added to the firstdimension but not to the second-dimension upper electrode buffer in the Kaltschmidt and Wittmann procedure, but in this case a stained zone with the same first-dimension mobility as spot $\mathrm{S} 3$ in Fig. 3A remains in the first-dimension gel (results not shown). To locate the migration position of protein S3 in the one-dimensional SDS gel electrophoresis migration pattern of $40 \mathrm{~S}$ subunit proteins, spots containing proteins S3, $S 5, S 7$, and $S 8$ (revised numbering of $40 S$ subunit proteins) were removed from a two-dimensiona! gel slab and their protein contents were eluted and examined by one-dimensional SDS gel electrophoresis. Figure 4 shows that protein S3 migrates in $40 \mathrm{~S}$ subunit protein band $\mathrm{D}$ with protein S7. Its molecular weight is estimated to be 43000 .

(3) A tail of stained material ending in a distinct, more strongly stained region (S10, Fig. 3A, revised numbering of $40 \mathrm{~S}$ subunit proteins) appears in the Kaltschmidt and Wittmann second-dimension gel slab vertically below the first-dimension sample zone. This trail is not seen if second-dimension electrophoresis is carried out with urea-free upper electrode buffer (e.g., Fig. 4A in [1]). After two-dimensional electrophoresis according to Zinker and Warner using urea-free electrode buffers, a trail of stained material appears in the final gel slab vertically below the first-dimension sample zone (see Fig. $5 \mathrm{~A}$ in [1]). A similar but less intense trail is seen when first-dimension upper electrode buffer contains $6 \mathrm{M}$ urea (Fig. 3B). To identify the protein or proteins present in these trails, they were excised from two-dimensional gels prepared with upper electrode buffer containing $6 \mathrm{M}$ urea and cut into sections as indicated in Fig. $3 \mathrm{~A}$. and 


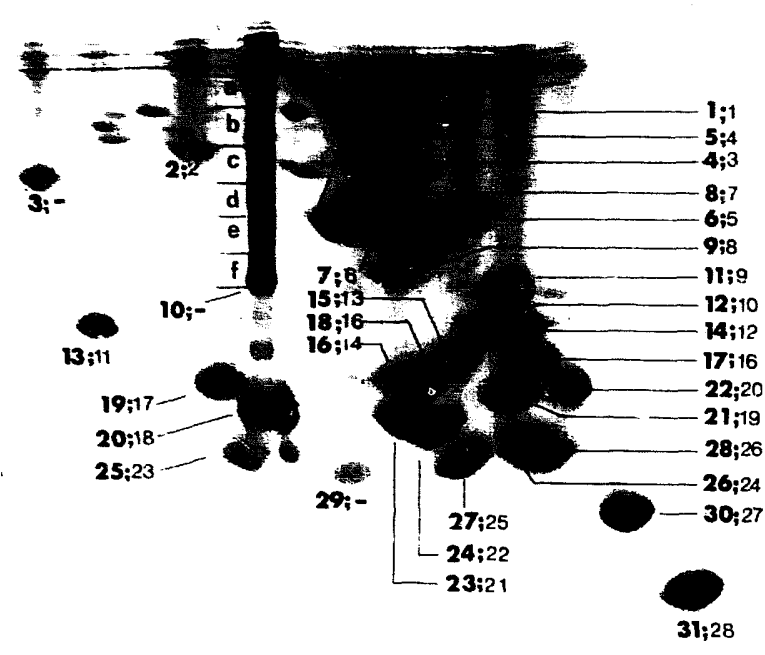

32;29

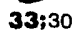

$34 ; 32$

$\mathbf{A}$

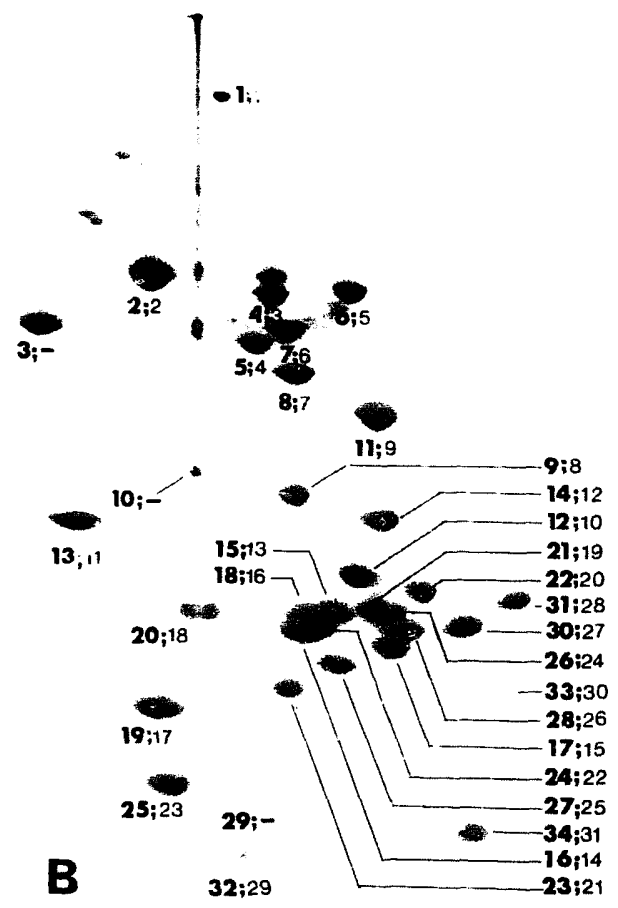

these were subjected to electrophoresis in onedimensional SDS-containing gels with control total $40 \mathrm{~S}$ subunit proteins. Figure 5 shows the results obtained with the stained central trail taken from a Kaltschmidt and Wittmann gel. All sections of the trail contained a major component migrating at the position of band $\mathrm{H}$ together with smaller amounts of other materials, and the concentration of the major component was greatest in the more strongly stained zone at the lower end of the trail.

A similar analysis (results not shown) of a stained trail taken from a Zinker and Warner gel revealed the presence, as expected, of band $\mathrm{H}$ protein at a position corresponding to its molecular weight and to traces of several larger and smaller $40 \mathrm{~S}$ subunit proteins. We conclude that protein S10 (revised numbering) present in $40 \mathrm{~S}$ $\mathrm{H}$ (Fig. 1A) has a pI of or close to 8.6, is insoluble in the absence of urea, and is poorly soluble and displays a tendency to aggregate even in the presence of high concentrations of urea. These properties cause its retention in the first-dimension sample zone of two-dimensional electrophoresis according to Kaltschmidt and Wittmann, unless urea is added to electrode buffers.

(4) A weakly stained spot previously seen nonreproducibly in two-dimensional separations of $40 \mathrm{~S}$ subunit proteins (dotted outlines in the verticals through spots $\mathrm{S} 4$ and $\mathrm{S} 29$ at positions southwest of $S 21$ of Fig. $4 B$ in $[1]$, and north of $\mathrm{S} 29$ in Fig. $5 \bar{B}$ in [1], protein numbering as in [1]) appears reproducibly as a relatively strongly stained spot (S29 in Fig. 3A, B, revised numbering of $40 \mathrm{~S}$ subunit proteins). The similarity of the electrophoretic mobilities of $40 \mathrm{~S}$ band $\mathrm{U}$ in Fig. 1 and of spot S29 in Fig. 3B (second-dimension mobility) suggested that they contained the same

Fig. 3. Two-dimensional electrophoretic analysis of total proteins of the $40 \mathrm{~S}$ ribosomal subunits of $T$. thermophila according to Kaltschmidt and Wittmann [6] and Zinker and Warner [7]. Ribosomal proteins were prepared for analysis and two-dimensional electrophoresis was carried out as described in Materials and methods.

A, 40S subunit proteins separated by electrophoresis according to Kaltschmidt and Wittmann.

B, $40 S$ subunit proteins separated by electrophoresis according to Zinker and Warner.

Bold numbers: Revised protein numbering. Light numbers: Original protein numbering [1]. The prefix $S$ (small) is omitted to simplify the figure. Formation of double spots by proteins S4, S29, and S33 (revised numbering) in the Zinker and Warner two-dimensional procedure, which is evident in Fig. 7B, is frequently observed in the case of $S 29$ but rarely in that of S4 and S33. None of these proteins forms a double spot in the Kaltschmidt and Wittmann two-dimensional procedure (Fig. 3A). 
protein. This was confirmed by removing band U from a one-dimensional SDS-polyacrylamide gel in which [ ${ }^{35}$ S] methionine-labeled $40 S$ subunit proteins had been separated, eluting its protein content, and examining the eluted material by two-dimensional electrophoresis according to Kaltschmidt and Wittmann. Figure 6 shows that the $\left[{ }^{35} \mathrm{~S}\right]$ methionine-labeled material eluted from band U migrates with spot S29.

\section{$60 S$ subunit proteins}

Figure 7A, B shows the results obtained by two-

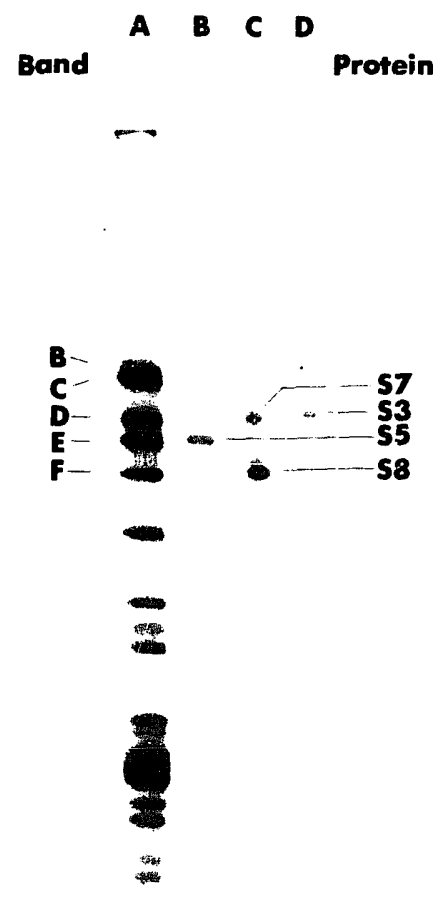

Fig. 4. Additional 40S subunit protein $\mathrm{S3}$ (revised numbering) migrates in band $D$ of the migration pattern of $40 \mathrm{~S}$ subunit proteins obtained by one-dimensional SDS-polyacrylamide gels. Proteins were eluted as described in Materials and methods from spots $\mathrm{S} 3, \mathrm{~S} 5$, and $\mathrm{S} 7+\mathrm{S} 8$ taken from a heavily loaded gel slab similar to that shown in Fig. 3A (twodimensional separation according to Kaltschmidt and Wittmann; spots S7 and S8 are poorly resolved and were eluted together) and concentrated from the eluates by precipitation with trichloroacetic acid without added carrier proteins.
A, Total 40 S subunit proteins.
B, Material eluted from spot S5.
C, Material eluted from spots $\mathbf{S 7}+\mathbf{S} 8$.
D, Material eluted from spot S3.

dimensional electrophoresis of total $60 \mathrm{~S}$ subunit proteins using urea-containing upper electrode buffers. Comparison with the results obtained previously (Fig. 4C, 5C in [1]) reveals three differences:

(1) The appearance of an additional weakly basic protein with low electrophoretic mobilities in both dimensions (L3, Fig. 7A, B, revised numbering of $60 \mathrm{~S}$ subunit proteins). To identify this protein in the one-dimensional SDS polyacrylamide gel electrophoretic pattern of $60 \mathrm{~S}$ subunit proteins, spots L3 and L5 (revised numbering)

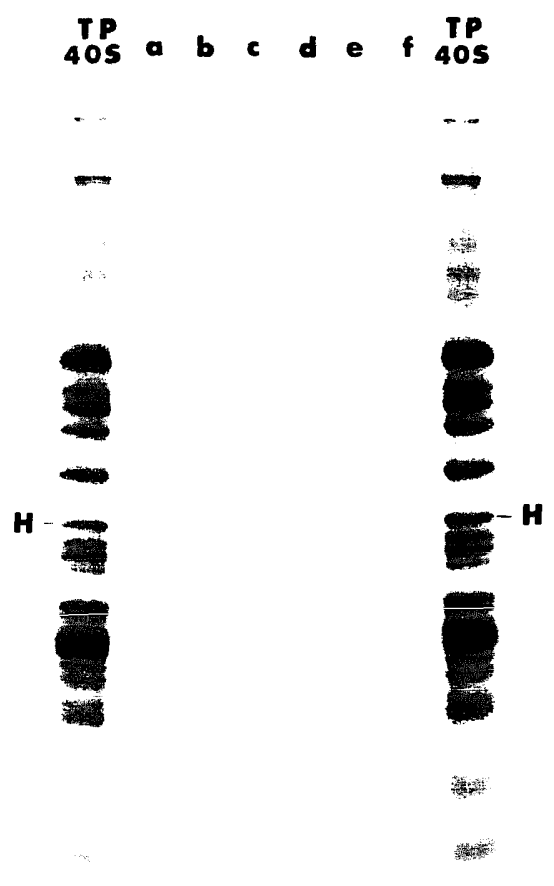

Fig. 5. One-dimensional SDS polyacrylamide gel electrophoresis of material eluted from the stained trail extending vertically below the first-dimension sample zone in twodimensional Kaltschmidt and Wittman analyses of total $40 \mathrm{~S}$ subunit proteins.

The stained trail below the first-dimension sample zone in the gel slab shown in Fig. 3A was removed in six sections as indicated. Protein was eluted from each section and concentrated by precipitation with trichloroacetic acid (Materials and methods) without addition of carrier proteins. The products were analyzed by one-dimensional SDS-polyacrylamide gel electrophoresis according to Laemmli [5].

$\mathbf{a}, \mathbf{b}, \mathbf{c}, \mathbf{d}, \mathbf{e}, \mathbf{f}$, Material eluted from sections $\mathbf{a}-\mathbf{f}$ indicated in Fig. 3A. The position of $40 \mathrm{~S}$ subunit protein band $\mathrm{H}$ is indicated. 
were removed from a two-dimensional gel similar to that shown in Fig. 7A and their protein contents were eluted and examined by onedimensional SDS polyacrylamide gel electrophoresis. Figure 8 shows that protein $\mathrm{L} 3$ migrates in $60 \mathrm{~S}$ band $\mathrm{D}$ already known to contain proteins L6 and L7 (revised numbering of $60 \mathrm{~S}$ subunit proteins). Its molecular weight is therefore
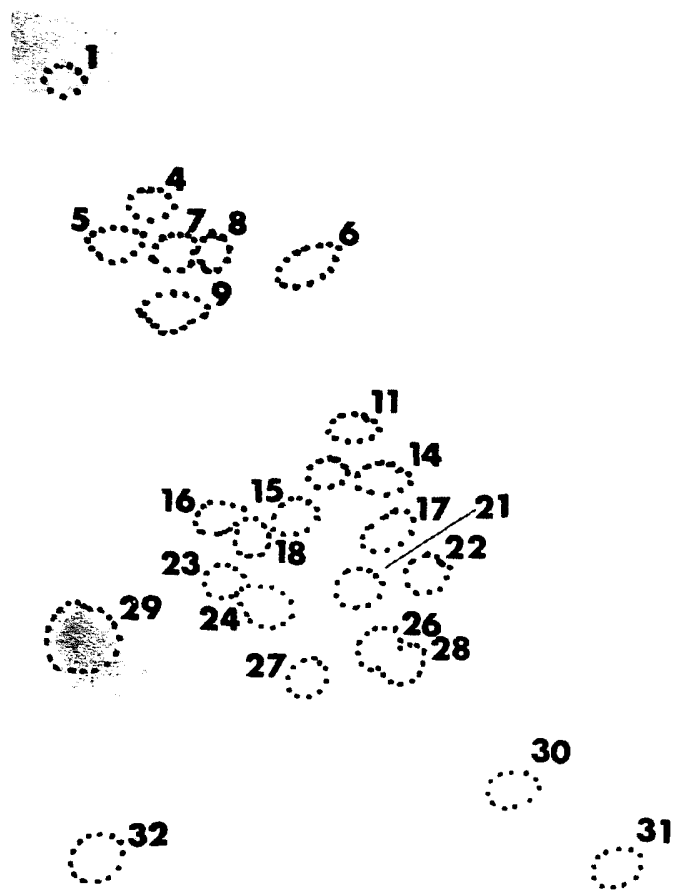

33

Fig. 6. $40 \mathrm{~S}$ subunit protein $\mathrm{S} 29$ (Fig. 3A, B, revised numbering) migrates in band $U$ of the one-dimensional SDS-polyacrylamide gel electrophoresis pattern of $40 \mathrm{~S}$ subunit proteins.

Band U (Fig. 1) was removed from a one-dimensional SDS-polyacrylamide gel in which ${ }^{35} \mathrm{~S}$-labeled $40 \mathrm{~S}$ ribosomal subunit proteins $\left(20 \mu \mathrm{g}\right.$ protein, sp. act. $\left.10^{5} \mathrm{cpm} / \mu \mathrm{g}\right) \mathrm{had}$ been separated, and its protein content was eluted and recovered by precipitation with trichloroacetic acid after addition of $120 \mu \mathrm{g}$ of total unlabeled $40 S$ subunit proteins (Materials and methods). The product was analyzed by two-dimensional electrophoresis according to Kaltschmidt and Wittmann ([6] basic proteins only) and the gel slab was stained, dried, and autoradiographed. Fig. 6 shows the autoradiograph upon which the spot contours of stained 40S subunit proteins have been added. Protein numbering as in fig. $3 \mathrm{~A}$; prefix $\mathbf{S}$ omitted to simplify the figure. approximately 40000 . It may be noted that no additional acidic spots and no cu.tral stained zones are visible in Figure 7A, B.

(2) Two weakly stained spots seen nonreproducibly in previous analyses of $60 \mathrm{~S}$ proteins by the Zinker and Warner procedure (dotted outlines below spot L22, and above and to the left of spot L30 in Fig. 5D in [1], protein numbering as in [1]) appear as strongly stained spots, L25 ar: $\mathrm{U}$ L2U in Fig. 7B (revised protein numbering). Analysis of the same $60 \mathrm{~S}$ subunit protein preparation by the Kaltschmidt and Wittmann procedure using $6 \mathrm{M}$ urea-containing upper electrode buffers (Fig. 7A) does not reveal additional spots corresponding to L25 and L20 in Fig. 7B, suggesting that the materials present in these two spots comigrate with other 60S subunit proteins in this procedure. Spots with the same first-dimension mobility as spots L25 and L20 in Fig. 7B were therefore removed from a gel slab similar to that shown in Fig. 7A (spots numbered L14, L19 + L20, L24 + L25, and L29 in Fig. 7A, and L13, L18, L22, and L26 in our earlier report [1]) and their protein contents were examined by one-dimensional SDS polyacrylamide gel electrophoresis [5]. The results of this analysis showed that two of the excised spots each contained one extra protein in addition to those detected in earlier analyses (see above) of the same spots taken from gel slabs in which two-dimensional electrophoresis of total $60 \mathrm{~S}$ subunit proteins was carried out with urea-free electrode buffers. These two spots are those designated L19 + L20 and L24 + L25 in Fig. 7A. The molecular weights of the additional proteins that they contain, i.e $\mathrm{L} 25$ in spot $\mathrm{L} 24+\mathrm{L} 25$ and $\mathrm{L} 20$ in spot L19 + L20, estimated from their seconddimension migration in Fig. 7B are 21500 and 17500 , respectively.

(3) Improved resolution of low molecular weight basic proteins in the Zinker and Warner procedure led to partial resolution of the spot previously numbered L36 (Fig. 5D, in [1]) into two spots. Reexamination of earlier results shows that evidence suggesting the binary nature of this spot was present in Fig. 5C of our previous report [1]. When proteins were eluted from the two partly resolved zones of this spot, (excised from a gel slab similar to that shown in Fig. 7B) and reexamined by electrophoresis according to Kaltschmidt and Wittmann, they were found to correspond to the species previously numbered L36 and L38 (Fig. 4C, D in [1]) now revised to $L 39$ and $L 41$ (Fig. 7A, this report). Since the spot numbered L36 in Fig. 5C 
in [1] contained two proteins identified as L36 and L38 (earlier nomenclature), it was necessary to establish the identity of the protein present in the spot numbered L38 in Fig. 5C in [1] and L43 in Fig. 7B of the present report. To do this, proteins were eluted from spots L42, L43, and L44
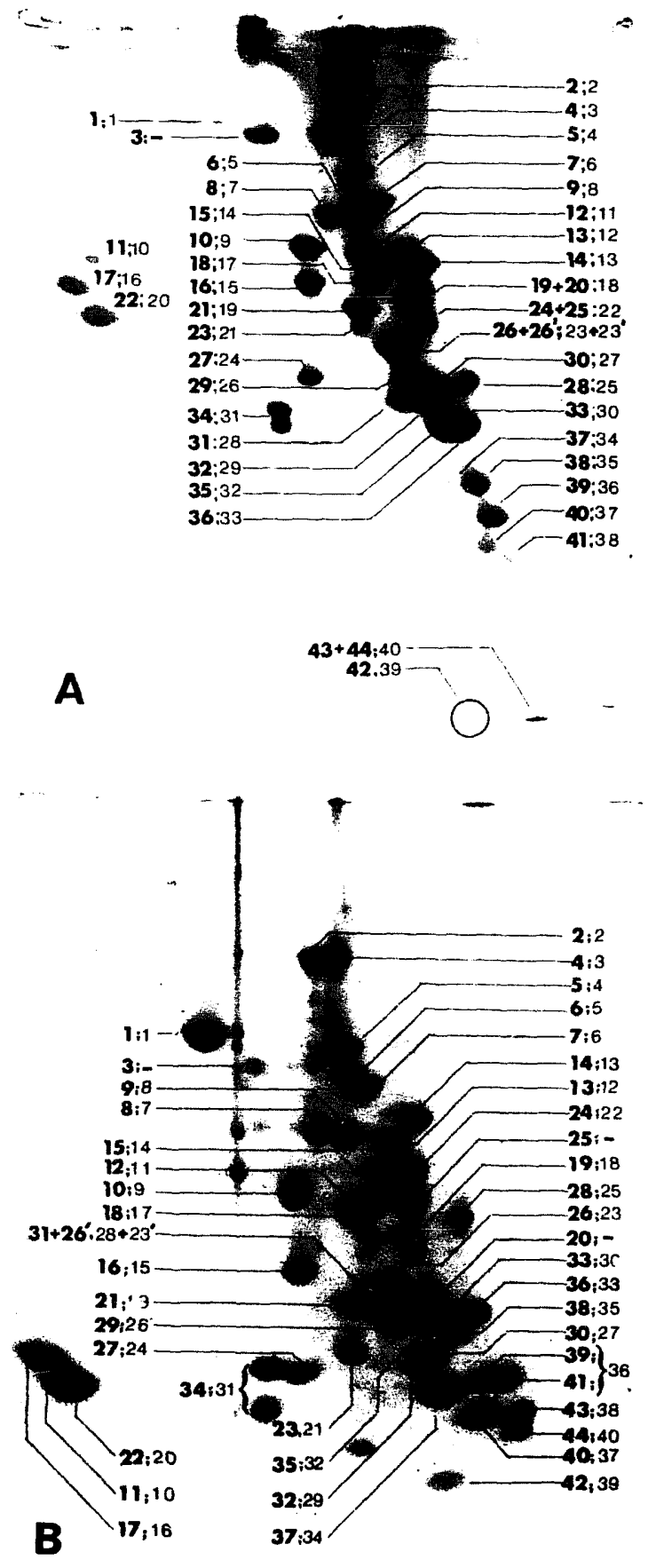

(revised nomenclature) taken from a gel slab similar to that shown in Fig. 7B and reexamined by electrophoresis according to Kaltschmidt and Wittmann (Figure 8).

Material eluted from spot L42 (Fig. 7B) migrated, as expected, with the front at the position previously numbered L39 (Fig. 4D in [1]); those eluted from spots L43 and L44 (Fig. 7B) also migrated at the front, both at the position previously numbered L40 (Figure 4D in [1]). It can be concluded that the spot previously numbered L40 in Kaltschmidt and Wittmann gels [1] contains two proteins which are well separated in the Zinker and Warner system (L43 and L44 in Fig. 7B). The second-dimension mobility of spot L43 in this system, very close to that of spot L40 (Fig. 7B) suggested that protein L43 was the species present in $60 \mathrm{~S}$ band $\mathrm{W}$ of Fig. 1B. This was verified by removing spot $\mathrm{L} 43$ from a Zinker and Warner gel, eluting its protein content, and comparing its mobility and that of total $60 \mathrm{~S}$ subunit proteins by a one-dimensional SDS gel electrophoresis (Fig. 8D).

\section{Conclusions}

The present report increases the number of proteins in the cytoplasmic ribosome of $T$. thermophila from 72 to 79 and, we believe, completes the catalogue of these proteins. Inclusion of the additional proteins does not significantly modify

Fig. 7. Two-dimensional electrophoretic analysis of total proteins of the $60 \mathrm{~S}$ ribosomal subunit of $T$. thermophila according to Kaltschmidt and Wittmann [6] and Zinker and Warner [7]. Ribosomal proteins were prepared and twodimensional electrophoresis was carried out as described in Materials and methods.

A, 60S subunit proteins scparated according to Kaltschmidt and Wittmann.

$\mathrm{B}, 60 \mathrm{~S}$ subunit proteins separated according to Zinker and Warner.

Bold numbers: Revised protein numbering. Light numbers: Original protein numbering [1]. The prefix L (large subunit) is omitted to simplify the figure. It may be noted that protein L34 (revised protein numbering) forms double spots in both two-dimensional electrophoresis systems. The intensities of staining of the two components of this double spot vary widely when different preparations of $60 \mathrm{~S}$ subunit proteins are analyzed and, in some cases, only a simple spot is seen. The stained spot containing protein $\mathrm{L} 42$, which does not appear in Fig. 7A, was weak but evident in the original stained gel slab. This protein appears as a relatively strongly stained spot in Fig. 7B. 
the overall composition of this ribosome or the average molecular weight of its proteins now estimated to be 23200 (previously 23100 , [1]), and leaves unaltered our earlier conclusion [1] that the value of this parameter is closer to that found for cytoplasmic ribosomes of higher than of lower eukaryotic organisms.

The presence of a high molecular weight basic protein comparable in these respects to protein S1 of the Escherichia coli ribosome [14] has not been observed in studies of other eukaryotic ribosomes (rabbit reticulocytes, [15, 16]; rat, rabbit, mouse, and chicken liver [15, 17-19];

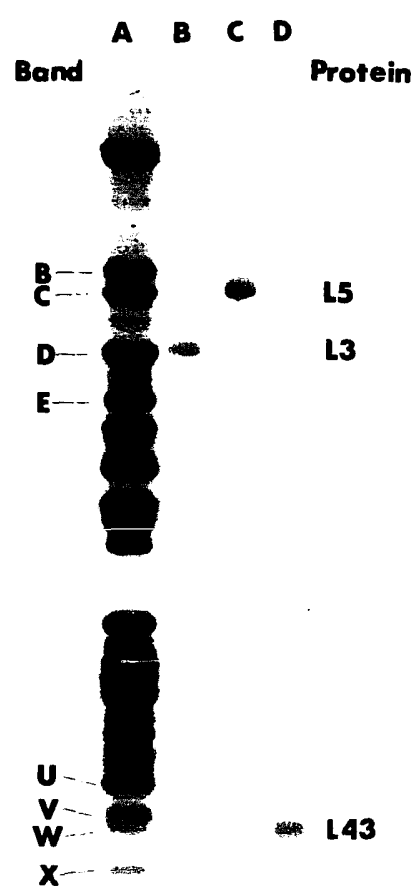

Fig. 8. Additional 60S subunit proteins L3 and L43 (revised nomenclature) migrate in bands $\mathbf{D}$ and $\mathbf{W}$, respectively, of the migration pattern obtained by separation of $60 \mathrm{~S}$ subunit proteins in one-dimensional SDS polyacrylamide gels.

Proteins were eluted from spots L3, L5, and L43 of a gel slab similar to that shown in Fig. 7A, concentrated from the eluates by precipitation with trichloroacetic acid without added carrier proteins, and analyzed by one-dimensional SDS-polyacrylamide gel electrophoresis according to Laemmli, [5].

A, Total $60 \mathrm{~S}$ subunit proteins.

B, C, D, Material eluted from spots L3, L5, and L43. Selected bands are identified on the left side of the figure.
Bombyx mori [20]; Saccharomyces carlsbe:gensis [21], S. cerevisiae [22]; etc.).

Reproducible observation of $40 \mathrm{~S}$ band A spot $\mathrm{S} 1$ in one- and two-dimensional analyses of a very large number of different preparations of ribosomes of $T$. thermophila, and a significant increase in the staining intensity of spot S1 when urea-containing electrode buffers are used in two-dimensional analyses, leave no doubt that the protein in spot $\mathrm{S} 1$ is a component of the small subunit of this ribosome.

Three of the seven additional proteins of the Tetrahymena ribosome, S3, S10, and L3, are not observed in the Kaltschmidt and Wittmann twodimensional gel electrophoresis procedure unless both first- and second-dimension electrode buffers in contact with protein samples and first-dimension gels contain a high concentration of urea. These proteins are also not observe ${ }^{d} n$ the $\mathrm{pH}$ 8.6-SDS $\mathrm{r}$ - ocedure of Zinker and war ner if urea is omitted from the first-dimensio : upper electrode buffer, and $:$ wo $\mathrm{e}^{\mathrm{th}} \mathrm{r}$ - additional proteins $\mathrm{L} 20$ and $\mathrm{L} 30$ do ${ }^{\circ} \mathrm{O}^{ \pm}$apF. $\ldots$ repriducibly in significant amounts under these corditons.

These results emphasize the importance, particularly in the case of the initial characterization of ribosomal proteins, of using the urea-containing first-dimension electrode buffer originally specified by Kaltschmidt and Wittmann, and, in addition, of adding urea to their second-dimension electrode butfer. We note that low solubility of at least one protein of the large subunit of the E. coli ribosome (L20) has been observed in the first dimension of the Kaltschmidt and Wittmann procedure when urea-free electrode buffer is used $[12,23]$.

\section{Acknowledgments}

The work described here was supported by grants from the Centre National de la Recherche Scientifique and the Fondation Nationale pour la Recherche Médicale Française.

\section{References}

1 Pétridou B., Cuny M., Guérin M.-F. \& Hayes F. (1983) Eur. J. Biochem. 135, 425-434

2 Cuny M., Milet M. \& Hayes D.H. (1982) Biochimie 64, 1049-1058

3 Sripati C.E. (1987) J. Gen. Microbiol. 133, 2581-2588

4 Pétridou B., Guérin M.-F. \& Hayes F. (1988b) Biochimie 71, 667-679

5 Laemmli U. (1970) Nature 227, 680-685 
6 Kaltschmidt E. \& Wittmann H.G. (1970) Anal. Biochem. 36, 401-412

7 Zinker S. \& Warner J.D. (1976) J. Biol. Chem. $251,1799-1807$

8 Hayes F. \& Guérin M.-F. (1987) Biochimie 69, 975-982

9 Sherton C.C. \& Wool I.G. (1972) J. Biol. Chem. $247,4460-4467$

10 Howard G.A. \& Traut R.R. (1973) FEBS Lett. $29,177-180$

11 Lastick S.M. \& McConkey E.H. (1976) J. Biol. Chem. 251, 2807-2875

12 Madjar J.J., Michel S., Cozzone A.J. \& Reboud J.P. (1979) Anal. Biochem. 92, 174-182

13 McConkey E.H., Bielka H., Gordon J., Lastick S.M., Lin A., Ogata K., Reboud J.P., Traugh J.A., Traut R.R., Warner J.R., Welfle H. \& Wool I.G. (1979) Mol. Gen. Genet. 169, 1-6

14 Kimura M., Foula is K., Subramanian A.R. \& Wittmann-Liebold B. (1982) Eur. J. Biochem. $123,37-53$
15 Martini O.H.W. \& Gould H.J. (1975) Mol. Gen. Genet. 142, 317-331

16 Madjar J.J. \& Traut R.R. (1980) Mol. Gen. Genet. 179, 89-101

17 Welfle H., Goerl M. \& Bielka H. (1978) Mol. Gen. Genet. 161, 101-112

18 Wool I.G. (1980) in: Ribosomes: Structure, Function and Genetics (Chambliss G., Craven G.R.. Davies J., Davis K., Kahan L. and Nomura M., eds.), University Park Press, Baltimore MD, pp. 797-824

19 Madjar J.J., Arpin M., Buisson M. \& Reboud J.P. (1979) Mol. Gen. Genet. 171, 121-134

20 Madjar J.J. \& Fournier A. (1S81) Mol. Gen. Genet. 182, 273-278

21 Bollen G.H.P.M., Mager W.H. \& Planta R.J. (1981) Mol. Biol. Rep. 8, 37-44

22 Michel S., Traut R.R. \& Lee J.C. (1983) Mol. Gen. Genet. 191, 251-256

23 Kaltschmidt E. \& Wittman H.G. (1970) Proc. Natl. Acad. Sci. USA 67, 1276-1282 